\section{More attention to preventive health services needed for older persons in the United States of America ${ }^{1}$}

Key words: aged, preventive health services, health services accessibility, cost-benefit analysis, United States of America.

\footnotetext{
Based on: (1) Partnership for Prevention. A better Medicare for healthier seniors: recommendations to modernize Medicare's prevention policies. Washington, D.C.: Partnership for Prevention; 2003. (2) Partnership for Prevention. Report: Medicare should be dedicated to health, not just sickness [press release]. Available from: http://www.prevent.org [Internet site]. Accessed 13 May 2003.
}

Medicare, the health insurance program of the Government of the United States of America that covers older individuals in that country, should focus more on keeping older persons healthy by providing a broader range of preventive health services instead of just treating those persons when they become sick, according to a report recently released by the Partnership for Prevention, a nonprofit health policy research organization based in Washington, D.C.

Entitled A Better Medicare for Healthier Seniors: Recommendations to Modernize Medicare's Prevention Policies, the report calls for the Medicare program to cover more services that can extend the lives of older persons and appreciably improve their quality of life. "Medicare remains almost entirely a health insurance program making payments for diagnostic and treatment services once serious illnesses and injuries have occurred," emphasizes the report, which also says, "Disease prevention and health promotion should be given the same priority in Medicare as disease treatment and care."

The Medicare program was established in 1965. Medicare now covers some 40 million persons, including 34 million who are age 65 or over, 5.5 million younger disabled persons, and 240000 persons with end-stage renal disease. Medicare now costs the federal Government around US $\$ 250$ billion per year. It is projected that Medicare will serve 77 million persons by 2030 .

Medicare now covers just 10 preventive services. Three of them are for immunizations (pneumococcal pneumonia, influenza, and hepatitis B), and the other seven are screening tests (five for cancer: cervical, vaginal, breast, colorectal, and prostate; one for osteoporosis; and one for glaucoma).

Medicare should routinely cover a number of other preventive services, according to the report. In reaching that conclusion, the Partnership compared Medicare's coverage of preventive services for older persons with the ones recommended by the United States Preventive Services Task Force (USPSTF). The USPSTF is an expert advisory panel that is convened by the Government's Department of Health and Human Services. The USPSTF weighs scientific evidence to determine whether various services are effective in preventing disease and injury.

Among the preventive services recommended by the USPSTF for older persons and not covered by Medicare are diphtheria-tetanus booster vaccination; screening for visual acuity, hearing, depression, and lipid profiles; and counseling about smoking cessation, motor vehicle injury prevention, and healthy 
diet. In addition, the Partnership report points out, while Medicare does include coverage for prostate cancer screening through prostate-specific antigen and digital rectal examinations and for vaginal cancer through a pelvic examination, those tests lack sufficient evidence to warrant being recommended, according to the USPSTF.

Some of the preventive services that the Partnership recommends would produce cost savings for Medicare. Others would not reduce program expenses overall but would provide beneficiaries with more productive years of life for a reasonable cost and would provide better value than later treatments for the same medical conditions.

Adding Medicare coverage for new preventive services is extremely cumbersome. Decisions on which treatments to pay for after a senior becomes ill can be made administratively by the Centers for Medicare and Medicaid Services, which is the federal agency that oversees Medicare. In contrast, decisions on which preventive services Medicare will cover require legislative approval by the United States Congress. "As evidence accumulates about the values of specific preventive services, the gap between what is proven effective and what is covered by Medicare widens," notes the report. The Partnership report recommends that the Centers for Medicare and Medicaid Services be given the same decision-making authority for prevention that it has for treatment.

Another recommendation in the Partnership report is for the addition of a "Welcome to Medicare" examination for persons who turn 65 . The visit could help orient older persons to Medicare and the services that the program offers. The visit would incorporate an efficient medical evaluation with preventive health screenings and immunizations and counseling about health promotion and disease prevention.

Even now, many older persons don't make use of all the preventive services that are currently available through Medicare. The majority of beneficiaries are up to date for at least one preventive service, but few of the older persons are up to date on the full range of recommended preventive services. In 1999, for example, $91 \%$ of older women had received at least one preventive service, but only $10 \%$ of the women had been screened for cervical, breast, and colorectal cancer and immunized against influenza and pneumonia. There are also disparities by race and ethnic group and by income and education levels. In 2001, for instance, while $74 \%$ of persons of Asian heritage had been vaccinated for influenza, that was true for $68 \%$ of whites and $58 \%$ of African-Americans.

No one single intervention would be sufficient to encourage older persons to use preventive services, according to the report. Instead, a multifaceted approach is needed. One possible measure is the use of "standing order programs." These programs authorize care providers other than physicians to administer a preventive service, such as a vaccination, based on an institution- or physician-approved protocol without a physician's examination. Such programs can be used in inpatient and outpatient facilities, long-term care facilities, managed care organizations, pharmacies, and the workplace. Financial incentives, patient reminders, and patient education are also effective in increasing older persons' use of preventive services.

If Medicare placed more emphasis on preventive services, that could encourage private sector providers of health care to do that as well with persons of all ages in the United States, according to the Partnership report.

More information on the report is available from: Partnership for Prevention, 1015 18th Street, N.W., Suite 200, Washington, D.C. 20036, United States of America; telephone: (202) 833-0009; fax: (202) 833-0113; e-mail: info@prevent.org; and Web site: http://www.prevent.org.

\section{SINOPSIS}

\section{Se necesita prestar mayor atención a los servicios sanitarios preventivos destinados a adultos mayores en los Estados Unidos de América}

Medicare, el programa público estadounidense de seguro de salud que cubre a adultos mayores, debe concentrarse más en mantener a estos saludables y en ofrecer una gama más amplia de servicios sanitarios preventivos, en lugar de limitarse a atender a personas enfermas, de acuerdo con un informe publicado recientemente por Partnership for Prevention, una organización sin fines de lucro radicada en Washington, D.C. El informe, titulado A better Medicare for healthier seniors: recommendations to modernize Medicare's prevention policies, llama a que el programa de Medicare cubra más servicios capaces de prolongar la vida de personas de edad avanzada y de mejorar su calidad de vida. Hasta el momento, Medicare cubre solo 10 servicios preventivos. Tres de ellos son de inmunización (contra neumonía neumocócica, influenza y hepatitis B), y los siete restantes consisten en pruebas de tamizaje para diversos cánceres, osteoporosis y glaucoma. Medicare debe ampliar sus servicios preventivos habituales, según el informe, y abarcar la vacunación de refuerzo contra la difteria y el tétanos; el tamizaje de la agudeza visual, problemas auditivos, depresión y perfil de lípidos en suero; y el asesoramiento para abandonar el hábito de fumar, prevenir lesiones por accidentes automovilísticos y observar una dieta saludable. Algunos de los servicios preventivos propuestos por Partnership for Prevention podrían generar ahorros para Medicare. Otros no implicarían reducciones, pero ofrecerían a los beneficiarios más años de vida productivos a un costo razonable. Si Medicare hiciera mayor hincapié en los servicios preventivos, esto pudiera estimular a los servicios privados de salud a hacer lo mismo con las personas de cualquier edad en los Estados Unidos. 